\title{
LEUIT SI JIMATE WUJUD SOLIDARITAS SOSIAL MASYARAKAT DI KASEPUHAN SINARRESMI
}

\section{LEUIT SI JMAT AS SOCIAL SOLIDARITY COMMUNITY INFRASTRUCTURES IN SINARRESMI TRADITIONAL VILLAGE}

\author{
Risa Nopianti \\ Balai Pelestarian Nilai Budaya Jawa Barat \\ Jalan Cinambo No.136 Ujungberung - Bandung \\ e-mail: risanopianti@gmail.com
}

\begin{abstract}
Abstrak
Penelitian ini melihat hubungan antara solidaritas sosial yang terjadi pada masyarakat Kasepuhan Sinarresmi dalam memfungsikan leuit si jimat sebagai lumbung padi sosial, dengan kewenangan pimpinan adat dalam menjaga aturan adat. Aturan terkait pertanian tradisional maupun hasil dari pertanian padi beserta lumbungnya, tidak dapat dipisahkan satu dengan lainnya. Merujuk pada penelitian sebelumnya yang membahas fungsi leuit pada masyarakat adat, penelitian ini mencoba membahas pada sisi lain, sehingga salah satu fungsi leuit si jimat sebagai lumbung padi komunal dapat lebih terjabarkan. Dengan menggunakan metode kualitatif, penelitian ini menemukan bahwa terjadinya solidaritas sosial pada masyarakat di Kasepuhan Sinarresmi, tidak hanya muncul sebagai wujud kesetiakawanan dari persamaan status sosial dan keterikatan sebagai warga kasepuhan, tetapi juga didorong oleh adanya sistem kekuasaan pemimpin adat di Kasepuhan Sinarresmi yang bertugas menjaga kelangsungan tradisi dalam leuit si jimat sebagai wujud kongkrit solidaritas sosial.
\end{abstract}

Kata kunci: leuit, solidaritas sosial, kepemimpinan tradisional.

\begin{abstract}
Research is trying to see how between solidarity social relations that occur in society of Kasepuhan leuit Sinarresmi in functioning of leuit si jimat (talisman rice container) as social granary, with the authorize of traditional leaders in maintaining the customary rules. The rules related to traditional agriculture in general, and the results of that rice farming and their barn, cannot be separated between each other. Refer to previous studies that are still common in discussed the functions of leuit of the indigenous peoples in particular on Indigenous Unity of south Banten. By using qualitative methods got found that the social solidarity in society in Kasepuhan Sinarresmi in functioning leuit si jimat, not only appears as a manifest of solidarity of the equation social status and engagement as citizens kasepuhan, but also driven by the power system which in this case was conducted by traditional leaders in Kasepuhan Sinarresmi in charge of maintaining the continuity of tradition into leuit si jimat as the concrete manifestation of social solidarity.
\end{abstract}

Keywords: leuit, social solidarity, traditional leadership.

\section{A. PEndahuluan}

Masyarakat adat dan pertanian tradisional merupakan dua objek kajian budaya yang tidak dapat terpisahkan. Pertanian tradisional yang dikelola masyarakat adat mencakup tiga aspek sistem, yaitu sistem biofisik, ekonomi, serta sosial-budaya (Iskandar, 2001: 61). Sistem biofisik termasuk di dalamnya tanah, air, tumbuhan dan binatang; sistem ekonomi seperti produksi, distribusi, dan 
konsumsi; sedangkan aspek sosial budaya meliputi tata nilai dan praktik sosial. Secara umum sistem pertanian tradisional dapat dibedakan menjadi sistem pertanian ladang berpindah (huma) dan sistem pertanian menetap. Sistem pertanian ladang berpindah merupakan perkembangan peradaban masyarakat berburu dan meramu. Cara hidup nomaden memungkinkan mereka mengembangkan sistem pertanian ladang berpindah sebagai upaya adaptasi terhadap lingkungan tempat mereka tinggal. Sementara itu sistem pertanian menetap dianggap sebagai tingkat evolusi tertinggi dalam perkembangan masyarakat agraris (Soemarwoto, 1994: 266).

Perkembangan sistem pertanian dari tahapan terendah hingga tertinggi, secara umum merupakan upaya adaptasi masyarakat bersangkutan terhadap kondisi alam dan lingkungannya. Adaptasi diartikan sebagai usaha manusia untuk menyesuaikan diri terhadap lingkungan tertentu dalam mendayagunakan sumber daya untuk menanggulangi masalahnya (Adimihardja, 1992: 11). Proses adaptasi tersebut pada akhirnya melahirkan sebuah strategi yang dikembangkan manusia untuk bertahan di tengah lingkungan alamnya yang disebut strategi adaptasi. Menurut Bennet yang dikutip dari Adimiharjdja (1992: 10), bahwa strategi adaptasi adalah proses adaptasi antara manusia dengan lingkungan alam, di mana manusia mengembangkan tingkah laku yang sesuai dengan tatanan lingkungan.

Proses adaptasi antara manusia dengan lingkungannya juga terjadi pada masyarakat Sunda. Sama halnya dengan sistem pertanian di daerah lain, pada masyarakat Sunda juga dikenal dua sistem pertanian bercocok tanam, yaitu sistem perladangan berpindah (huma) dan sistem sawah. Kedua sistem pertanian itu pada awalnya berkembang dari hutan yang diubah manusia dengan menggunakan teknologi (Iskandar dan Iskandar, 2011: 40).
Sistem pertanian huma (ladang) merupakan sistem pertanian pertama yang dikenal oleh masyarakat Jawa Barat, dan hingga kini masih dipertahankan oleh beberapa komunitas adat, seperti komunitas adat Baduy, dan beberapa komunitas kasepuhan di Banten Kidul. Praktik perladangan berpindah (ngahuma) memiliki kaitan erat dengan keberadaan kawasan hutan. Ladang huma biasanya dibentuk dengan membuka lahan hutan (Iskandar dan Iskandar, 2011: 56), serta menggunakan sistem pengairan tadah hujan. Ladang huma biasanya ditanami padi tadah hujan, atau jenis tanaman musiman lainnya dan pemakaiannya hanya semusim atau dua musim kemudian akan ditinggalkan bila tidak subur lagi. Secara reguler perladangan huma berpindah tempat dari satu hutan ke hutan lainnya pada kurun waktu tertentu untuk menjaga tingkat kesuburan tanah.

Kemudian pada kira-kira tahun 1750 orang Jawa Tengah memperkenalkan sawah (Iskandar dan Iskandar, 2011: 37), sehingga sistem perladangan huma sedikit demi sedikit mulai ditinggalkan dan mulai beralih pada sistem sawah yang sifatnya menetap.

Sampai saat ini petani merupakan profesi utama masyarakat Sunda, dan pertanian sawah merupakan areal garapan utama mereka dalam bertani. Pada masa awal terbentuknya sistem pertanian sawah, masyarakat Sunda masih memegang tradisi bahwa mereka bertani tidak untuk mencari untung, karena itu ada peribahasa "petani tinggal senang, pedagang tinggal utang". Mereka bertani hanya supaya cukup makan dan pakaian (Mustafa, 2010: 104).

Lain halnya dengan pertanian sawah modern yang umum digarap oleh sebagian besar masyarakat saat ini, yang lebih menitikberatkan pada peningkatan hasil produksi pertanian melalui sistem intensifikasi pertanian ${ }^{1}$. Hal tersebut

\footnotetext{
${ }^{1}$ Intensifikasi pertanian atau Revolusi Hijau di Indonesia dimulai sejak tahun 1960-an. Revolusi Hijau sebenarnya mengacu pada program intensifikasi pertanian tanaman
} 
menyebabkan pertanian menjadi objek komersialisasi ekonomi, sehingga banyak petani yang bermodal kecil dirugikan oleh mereka yang memiliki modal lebih besar.

Nilai ekonomis yang tersemat pada sistem pertanian sawah yang banyak digarap oleh masyarakat saat ini berdampak pada terjadinya perubahan pola penggarapan sawah. Untuk tetap menjaga kesuburan tanah diberi asupan pupuk dan pestisida. Peralatan pertanian yang tadinya hanya menggunakan kapak, baliung, parang, kored dan alat tugal, berubah menggunakan alat yang lebih modern, seperti cangkul, bajak, traktor, dan sabit (Iskandar dan Iskandar, 2011: 42). Hal ini jelas meningkatkan biaya produksi yang akhirnya berimbas pada nilai jual gabah.

Konsep komersialisasi ekonomi pertanian inilah yang ditolak secara langsung oleh masyarakat adat khususnya di Kasepuhan Sinarresmi. Selain memang masyarakat adat secara turun temurun menganggap tabu atau pantang mengkomersialkan hasil pertanian khususnya padi, mereka juga beranggapan bahwa dengan tidak memperjualbelikan hasil panen padinya, kehidupan mereka akan senantiasa sejahtera, cukup pangan cukup makan. Sebuah pengharapan yang sederhana yang lahir dari masyarakat yang masih sederhana.

Berawal dari pemikiran inilah kemudian dibangun leuit sebagai rumah padi hasil panen. Selain sebagai tempat

pangan khususnya pertanian padi. Di Indonesia sendiri sebenarnya program intensifikasi sudah mulai dicoba pada waktu sebelum Indonesia merdeka pada tahun 1937. Tujuan program ini adalah untuk meningkatkan produksi tanaman padi yang untungnya juga peningkatan tersebut dapat diusahakan tanpa mengubah struktur sosial pedesaan. Pikiran dasarnya adalah produksi padi harus naik, sedangkan soal pembagian hasil pada gilirannya akan diatur oleh kekuatan atau mekanisme pasar sendiri. Dikutip dari http://www.omtani.com/2015/ 03/program-intensifikasi-pertanian-revolusihijau.html, diakses 2 Februari 2016 pukul 10.45 WIB. memuliakan padi kepada Sanghyang Sri, konsep leuit juga digunakan untuk menjaga ketahanan pangan masyarakat adat yang hanya melaksanakan panen raya satu tahun sekali. Lamanya rentang waktu antara satu panen ke panen selanjutnya, menyebabkan masyarakat adat tidak menjual hasil panennya, melainkan cukup menyimpannya saja di dalam leuit sebagai bekal kebutuhan sehari-hari.

Permasalahannya bahwa alam terkadang kurang bersahabat pada waktuwaktu tertentu, manakala terjadi kemarau yang berkepanjangan (paceklik) terkadang ada saja anggota masyarakat yang kekurangan stok padi di dalam leuitnya sehingga mereka harus meminjamnya. Keberadaan leuit si jimat yang merupakan jenis leuit bersama dianggap mampu menanggulangi masalah-masalah dasar kebutuhan manusia yang bersifat mendesak untuk dibantu. Konsep saling membantu inilah yang menjadi keunikan tersendiri dari keberadaan leuit komunal di Kasepuhan Sinarresmi.

Penelitian mengenai fungsi leuit telah banyak dilakukan oleh para peneliti bidang kebudayaan. Beberapa hasil penelitian yang telah ada di antaranya: Nina Merlina (2003) mengenai Fungsi Leuit bagi Masyarakat Desa Cidikit, Kecamatan Bayah, Kabupaten Lebak; Rosyadi dan kawan-kawan (2005) mengenai Peranan Leuit dalam Kehidupan masyarakat Kasepuhan Cisungsang di Desa Cisungsang, Kecamatan Cibeber, Kabupaten Lebak Banten, serta Yuzar Purnama dan kawan-kawan (2012) mengenai Fungsi Leuit pada Masyarakat Kasepuhan Cicarucub Banten.

Nina Merlina pada penelitian mengenai leuit di Kasepuhan Cidikit menyatakan bahwa leuit merupakan warisan budaya leluhur yang masih berguna dan dimanfaatkan oleh warga Cidikit, hingga saat ini baik bentuk maupun fungsinya belum berubah, sehingga perlu dilestarikan. Sedangkan penelitian leuit oleh Rosyadi dan kawankawan di Kasepuhan Cisungsang 
menyimpulkan bahwa leuit mempunyai fungsi sosial, ekonomi, dan budaya. Fungsi sosial leuit adalah sebagai penyedia bahan pangan pada saat warga membutuhkan bantuan stok pangan, fungsi ekonomi leuit karena padi yang disimpan di dalam leuit bisa dijual pada saat mereka membutuhkan uang, fungsi budaya sebagai media utama bagi berlangsungnya aktivitas ritual adat. Penelitian Yuzar Purnama dan kawankawan mengenai leuit di Cicarucub menemukan fungsi utama leuit adalah tempat penyimpanan gabah, leuit juga berperan ketika masyarakat mengalami masa paceklik atau kekurangan pangan.

Kemudian apa yang membedakan kajian mengenai penelitian ini dengan penelitian sebelumnya? Penelitian ini fokus terhadap fungsi leuit si jimat atau di beberapa tempat disebut juga leuit kasatuan atau leuit komunal, yang notabene merupakan leuit adat yang dimiliki bersama-sama oleh seluruh masyarakat di Kasepuhan Sinarresmi, sehingga fungsinya akan sedikit banyak memiliki perbedaan karena penulis melihatnya dari sisi pembentukan solidaritas sosial masyarakat yang kemungkinannya dipengaruhi oleh faktor kekuasaan terhadap keberadaan leuit si jimat. Bagaimana solidaritas sosial itu dibentuk kemudian diwujudkan, serta faktor apa yang melatarbelakangi terjadinya solidaritas sosial tersebut menjadi fokus pada penelitian ini.

\section{B. METODE PENELITIAN}

Penelitian ini menggunakan pendekatan metodologis kualitatif, yang disajikan dalam uraian yang bersifat deskriptif. Penelitian kualitatif merupakan penelitian yang digunakan untuk menyelidiki, menemukan, menggambarkan, dan menjelaskan kualitas atau keistimewaan dari pengaruh sosial yang tidak dapat dijelaskan, diukur atau digambarkan melalui pendekatan kuantitatif (Saryono, 2010: 1). Sementara menurut Creswell (dalam Herdiansyah, 2010: 8), menyebutkan:
"Qualitaive research is an inquiry process of understanding based on distinct methodological traditions of inquiry that explore a social or human problem. The researcher builds a complex, holistic picture, analizes words, report detailed views of information, and conducts the study in a natural setting".

Adapun pengumpulan data dilakukan melalui teknik observasi dan wawancara terfokus baik secara individu maupun kelompok. Pada bagian analisis data dilakukan proses pelacakan dan pengaturan secara sistematis dimulai dari transkrip wawancara, catatan lapangan dan bahanbahan lain, sehingga dapat ditafsirkan dan disajikan secara sistematis.

\section{Pendekatan Teoritis \\ a. Solidaritas Sosial}

Konsep solidaritas sosial terdiri atas dua kata yaitu solidaritas dan sosial. Solidaritas sosial dapat diartikan sebagai sebuah kondisi yang ada pada suatu kelompok, yang dibentuk oleh kepentingan bersama (Saifullah, 2015: 22).

Gagasan utama mengenai solidaritas sosial pertama kali dikembangkan oleh Emile Durkheim dalam bukunya "The Division of Labour in Society". Durkheim melihat bahwa setiap kelompok masyarakat memerlukan solidaritas. Durkheim berpendapat bahwa masyarakat dapat dibedakan dengan cara bagaimana mereka mencapai keteraturan. Pada masyarakat sederhana disatukan oleh kesamaan antaranggota, sedangkan masyarakat kompleks disatukan oleh perbedaan sosial (Scott, 2011: 268).

Menurut Durkheim bahwa solidaritas sosial adalah suatu keadaan yang menunjuk pada suatu keadaan hubungan antara individu dan atau kelompok yang didasarkan pada perasaan moral dan

\footnotetext{
${ }^{2}$ Pada hakikatnya analisis data adalah sebuah kegiatan untuk mengatur, mengurutkan, mengelompokkan, memberi kode atau tanda, dan mengkategorikannya sehingga diperoleh suatu temuan berdasarkan fokus atau masalah yang ingin dijawab.
} 
kepercayaan yang dianut bersama yang diperkuat oleh pengalaman emosional bersama (Jones, 2009: 123).

Kemudian Durkheim membedakan solidaritas sosial menjadi dua tipe utama, yaitu solidaritas mekanik dan solidaritas organik. Solidaritas mekanik merupakan suatu tipe solidaritas yang didasarkan atas persamaan. Menurut Durkheim solidaritas mekanik dijumpai pada masyarakat yang masih sederhana yang dinamakan masyarakat segmental. Pada masyarakat seperti ini belum terdapat pembagian kerja yang berarti. Dengan demikian tidak terdapat saling kebergantungan antara kelompok berbeda, karena masing-masing kelompok dapat memenuhi kebutuhannya sendiri dan masing-masing kelompok pun terpisah satu dengan yang lain. Tipe solidaritas yang didasarkan atas kepercayaan dan setia kawan ini diikat oleh apa yang oleh Durkheim dinamakan conscience collective yaitu suatu sistem kepercayaan dan perasaan yang menyebar merata pada semua anggota masyarakat.

Menurut James (2006: 56) ciri-ciri masyarakat dengan solidaritas mekanik ditandai oleh adanya kesadaran kolektif, dimana mereka mempunyai kesadaran untuk hormat pada ketaatan karena nilainilai keagamaan yang masih tinggi, menandai masyarakat yang masih sederhana, tinggal tersebar, dapat menjalankan peran yang diperankan orang lain, pembagian kerja belum berkembang, hukuman bersifat represif sehingga memperkuat hubungan di antara mereka.

Sementara solidaritas sosial organik dapat ditemukan pada masyarakat dengan masing-masing anggotanya tidak lagi dapat memenuhi semua kebutuhannya sendiri melainkan ditandai oleh saling kebergantungan yang besar dengan orang atau kelompok lain. Solidaritas organik merupakan suatu sistem terpadu yang terdiri atas bagian yang saling bergantung laksana bagian suatu organisme biologi. Berbeda dengan solidaritas mekanik yang didasarkan pada hati nurani kolektif maka solidaritas organik didasarkan pada hukum dan akal.

Pemikiran Durkheim mengenai solidaritas sosial lebih mengacu pada fenomena budaya daripada ekonomi, dan solidaritas ini tertanam dalam diri manusia melalui religi atau kehidupan duniawi yang seimbang, seperti kultus individu (Scott, 2011: 268).

\section{b. Kekuasaan dan Wewenang}

Kekuasaan adalah sebuah fenomena seseorang atau sekelompok orang yang memiliki kekuatan atau kemampuan untuk mengatur atau memerintah orang atau kelompok lain yang ada dalam masyarakat. Adapun wewenang diartikan sebagai kekuasaan yang melekat pada diri seseorang atau sekelompok orang yang telah mendapat dukungan dari masyarakat yang dikuasainya (Setiadi dan Kolip, 2011 : 745-746).

Menurut Mc. Iver bahwa faktor penyebab seseorang dapat menguasai pihak lain adalah karena adanya mitos dan hukum. Mitos merupakan kepercayaan yang mengandung nilai dan gagasan yang dimiliki manusia untuk memerintah hidup mereka (1980: 12).

Adapun sumber-sumber kekuasaan dapat diperoleh dari: militer/polisi, ekonomi, politik, hukum, tradisi, ideologi, dan discovery power (Soekanto, 2013: 232). Lebih khusus kekuasaan yang diperoleh dari tradisi turun temurun digunakan untuk melanggengkan sistem kepercayaan dan nilai-nilai yang telah dipercayai oleh pemegang kekuasaan dan pengikutnya.

Unsur-unsur kekuasaan dapat dilihat dengan adanya rasa takut, rasa cinta, kepercayaan, dan pemujaan. Dalam sistem pemujaan orang yang berkuasa mempunyai dasar pemujaan dari orang-orang lain, sehingga segala tindakan penguasa dibenarkan atau dianggap benar.

Adapun saluran kekuasaan dapat dijalankan melalui saluran militer, saluran ekonomi, saluran politik, saluran tradisional. Melalui saluran ini penguasa 
menyesuaikan dengan tradisi yang ada di dalam suatu masyarakat yang dikuasainya, dan saluran ideologi.

Sementara wewenang dapat dibedakan ke dalam tiga bagian, yaitu :

- Wewenang kharismatik, merupakan wewenang yang didasarkan pada kharisma atau kemampuan khusus yang ada pada diri seseorang.

- Wewenang tradisional, dimiliki oleh seseorang atau sekelompok orang yang sudah lama sekali mempunyai kekuasaan dalam suatu masyarakat tertentu.

- Wewenang rasional, merupakan wewenang yang didasarkan pada sistem hukum yang berlaku.

\section{Kerangka Pemikiran}

Sistem pelapisan sosial yang bersifat tertutup pada masyarakat Kasepuhan Sinarresmi, merupakan modal penting bagi pemimpin adat (Abah) untuk melanggengkan kekuasaannya secara turun temurun. Sesuai dengan konsep kepemimpinan tradisional yang mengutamakan pemujaan sebagai alat utama berjalannya pemerintahan maka solidaritas sosial yang terbentuk dalam pemanfaatan leuit dapat ditafsirkan sebagai bentuk terjadinya solidaritas mekanik. Solidaritas mekanik ini terjadi ketika anggota masyarakat merasa saling percaya dan memiliki rasa kesetiakawanan yang tinggi yang menyebar merata pada seluruh lapisan sosial. Selain itu solidaritas juga terbentuk karena adanya dorongan dari penguasa untuk berbuat demikian berdasarkan aturan adat yang telah ada sejak dulu dan masih dipatuhi oleh masyarakat hingga saat ini.

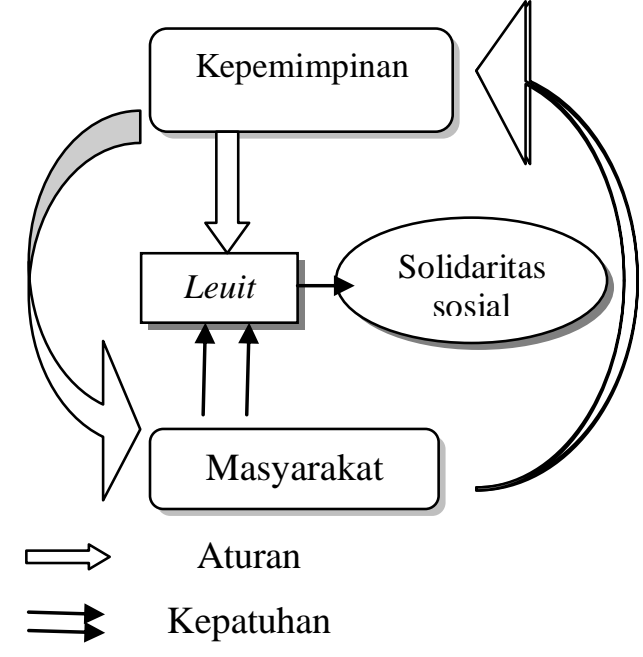

\section{Hipotesis}

Solidaritas sosial yang terbentuk pada masyarakat di Kasepuhan Sinarresmi dalam memfungsikan leuit si jimat sebagai sebuah lumbung padi sosial dapat terjadi karena adanya dorongan dari atas berupa sistem kekuasaan tradisional yang menjadi landasan dari semua aturan adat yang ada di Kasepuhan Sinarresmi. Abah sebagai pemimpin adat di Kasepuhan Sinarresmi memiliki kewenangan tersendiri yang bersifat tradisional dan kharismatik untuk mengatur tata kehidupan sosial, agama, politik, dan budaya masyarakatnya sehingga setiap titah, ucapan dan perkataan sepuh merupakan sebuah kewajiban yang harus dipatuhi.

\section{HASIL DAN BAHASAN \\ 1. Gambaran Umum Desa Sinarresmi}

Kasepuhan merupakan sebuah komunitas adat yang secara geografis berada di sekitar wilayah Taman Nasional Salak Halimun. Pengertian komunitas adat merujuk pada kehidupan sekelompok orang yang hidup di suatu wilayah tertentu, dan warganya relatif masih kuat mempertahankan tradisi warisan leluhur dalam kehidupannya sehari-hari (Rosyadi, dkk, 2005: 6). Sementara kasepuhan sendiri menamakan dirinya sebagai warga kasatuan atau kesatuan, yang menurut Kusnaka Adimihardja (1992: 4) warga kasatuan atau kasepuhan menunjukkan suatu kelompok sosial yang memiliki 
keseragaman dalam pola perilaku kehidupan sosial budaya. Sedangkan sebutan kasepuhan menunjuk pada suatu sistem kepemimpinan dari suatu komunitas di mana semua aktivitas anggotanya berdasarkan adat kebiasaan para orang tua (sepuh atau kolot) (Adimihardja, 1992: 4).

Komunitas adat kasepuhan ini memiliki kekhasan tersendiri yang membedakannya dari kelompok masyarakat lainnya, seperti memiliki pimpinan adat yang disebut $A b a h$, menjadikan pertanian tradisional sebagai mata pencaharian utama hidupnya, hidup berkelompok dengan mengindukkan diri kepada satu pimpinan adat (Abah), kuat menjalankan tradisi dan amanat leluhur melalui berbagai ritual dan upacara kepercayaan, memiliki rumah adat sebagai pusat pemerintahan, serta leuit sebagai tempat penyimpanan padi (media ketahanan pangan).

Komunitas adat Kasepuhan Sinarresmi merupakan salah satu dari sekian banyak komunitas adat yang berada di wilayah pegunungan Taman Nasional Salak Halimun. Kasepuhan Sinarresmi secara administratif berada di Desa Sirnaresmi, Kecamatan Cisolok, Kabupaten Sukabumi. Terdapat tiga komunitas kasepuhan yang berpusat di Desa Sirnaresmi, yaitu Kasepuhan Sinarresmi, Kasepuhan Cipta Mulya, dan Kasepuhan Cipta Gelar.

Komunitas Adat Kasepuhan Sinarresmi tergabung ke dalam sebuah organisasi komunitas adat yang bernama SABAKI (Kesatuan Adat Banten Kidul) bersama beberapa komunitas adat lainnya yang tinggal di sekitar Gunung Halimun, terutama di wilayah Kabupaten Sukabumi sebelah barat hingga ke Kabupaten Lebak, dan ke utara hingga ke Kabupaten Bogor.

Kasepuhan Sinarresmi memiliki sebuah rumah adat yang dinamakan imah gede, yang berfungsi sebagai pusat kegiatan adat dan rumah tinggal $a b a h$, juga berfungsi sebagai rumah bagi para tamu yang datang berkunjung. Selain imah gede juga terdapat bale pertemuan adat dan leuit komunal yang disebut leuit si jimat
Bangunan-bangunan ini biasanya dibangun dalam satu komplek yang berdekatan untuk memudahkan aktivitas adat.

Tata nilai yang dianut oleh komunitas adat Kasepuhan Sinarresmi bukan hanya terkait aspek sosial-budaya semata akan tetapi terintegrasi pula dengan aspek lainnya seperti sistem ekonomi dan lingkungan hidup. Bertani merupakan mata pencaharian utama masyarakat di Kasepuhan Sinarresmi. Pertanian tradisional yang mereka garap sangat bergantung pada ketersediaan sumber daya air. Oleh karena itu masyarakat adat sangat menjaga kelestarian hutan yang merupakan sumber air demi keberlangsungan kehidupan mereka.

Dalam kelembagaan adat, telah diatur tugas-tugas yang harus dilaksanakan oleh setiap warga adat kasepuhan untuk berperan serta menjaga keseimbangan ekosistem lingkungan. Ngajaga leuweung dengan segala peraturan adat yang melekat kepadanya merupakan salah satu bentuk kepedulian masyarakat adat kasepuhan dalam menjaga dan melestarikan hutan.

Yang menarik dari Kasepuhan Sinarresmi adalah terkait dengan penjagaan adat dalam pengelolaan sistem pertanian padi yang mereka lakukan. Bagi komunitas adat Kasepuhan Sinarresmi, bertani bukan hanya sekadar aktivitas ekonomi terkait menanam, memelihara dan memanen. Lebih dari itu, bertani adalah bagian dari nafas budaya dan penjagaan adat tradisi leluhur mereka. Oleh karena itu sistem pertanian yang diterapkan di Kasepuhan Sinarresmi terus dijaga melalui aturan adat istiadat dan dipantau secara langsung oleh Abah sebagai ketua adat.

Falsafah hidup warga Kasepuhan Sinarresmi dalam mengagungkan padi sebagai sumber kemakmuran dan kesejahteraan hidup mereka tercermin dalam pepatah berikut ini:

"buncir leuit loba duit, murah sandang, murah pangan, teu orot ku dicokot, teu guntang ku didahar, saeutik mahi loba nyesa".

Artinya, leuit penuh banyak uang, sandang murah, pangan juga murah, 
tidak habis diambil, tidak lapar dimakan, sedikit cukup banyak bersisa. Lebih jauh diartikan sebagai bentuk keberkahan apabila masyarakat senantiasa menjaga keberadaan sistem pertanian yang telah diwariskan oleh leluhur mereka. Sehingga hasilnya dapat dirasakan yaitu padi tidak akan pernah habis.

Sistem pertanian tradisional dengan pola menetap atau disebut sawah $^{3}$ merupakan perkembangan dari sistem pertanian huma yang awal mulanya mereka kembangkan, sebagaimana yang saat ini masih dapat ditemui pada komunitas adat tradisional Kanekes. Namun sisa-sisanya masih dapat ditemukan juga pada masyarakat di Kasepuhan Sinarresmi. Hal ini dapat dilihat dari masih adanya jenis padi ladang atau huma atau tadah hujan, selain padi sawah jenis lokal yang masih mereka kembangkan ${ }^{4}$.

\section{Sistem Kepemimpinan Tradisional Kasepuhan Sinarresmi}

Komunitas adat Kasepuhan Sinarresmi dipimpin oleh seorang pimpinan adat yang dipanggil Abah. Abah Asep Nugraha nama lengkap dari pemimpin adat Kasepuhan Sinarresmi saat ini, merupakan pimpinan adat kesepuhan yang dapat ditelusuri dari peninggalan makam karuhun yang ada di Kasepuhan Sinarresmi (Rahmawati ddk., 2008: 173). Beliau merupakan simbol adat kasepuhan yang dijadikan panutan dan tuntunan oleh seluruh warganya.

Dalam menjalankan aktivitas pemerintahan adat sehari-hari Abah dibantu oleh seorang wakil dan sekretaris. Selain itu, terdapat juga seorang penasihat ahli

3 Sistem pertanian tradisional sawah merupakan adaptasi terhadap daerah bergunung dan bercurah hujan tinggi yang terlanjutkan dan terjamin (Soemarwoto, 1994: 268).

4 Padi lokal di Kasepuhan Sinarresmi yang masih ada sebanyak 50 jenis padi sawah dan 11 jenis padi huma (ladang). bidang agama. Sedangkan secara struktural kenegaraan Abah dibantu oleh beberapa orang bawahannya yang mempunyai jabatan dan fungsinya masing-masing. Mereka terdiri atas dukun, panghulu, kolot lembur, tukang moro, tukang paraji, tukang bersih, tukang suguh, tukang benteng, tukang kemit, tukang goah, tukang sisiuk, dan tukang canoli. Seluruh staf Abah tersebut disebut juga baris kolot atau olot $^{5}$.

Menurut Rahmawati (2008: 173), keberadaan sekretaris dalam sistem pemerintahan Kasepuhan Adat Sinarresmi relatif baru, yaitu sebagai hasil bentukan Abah Asep yang ditujukan untuk mengikuti arah perubahan zaman. Fungsi sekretaris sendiri adalah sebagai orang yang dapat mewakili Abah dalam berhubungan dengan dunia luar. Selain itu dalam sistem pemerintahan internal, sekretaris juga berfungsi untuk mencatat jumlah warga kasepuhan (incu putu) dan jumlah hasil panen padi yang dihasilkan oleh seluruh warga kasepuhan pada saat menjelang upacara seren taun.

Sementara itu kolot lembur ditunjuk langsung oleh abah yang bertugas mewakili Abah di masing-masing rendangan ${ }^{6}$. Menurut Abah Asep saat ini terdapat sekitar 111 (seratus sebelas) rendangan yang ada di Kasepuhan Sinarresmi. Kolot lembur juga bertugas mengelola tanah milik Abah yang ada di wilayahnya dengan sistem bagi hasil. Sebagaimana diucapkan Abah sebagai berikut:

"Pami abah tos gaduh leuit seueur, nu ngurus teh tiasa kolot lembur. Nu mimpin rendangan nyaeta kolot lembur. Pami nuju kagok di dieu, tiasa nunjuk ka hiji lembur pang nutukeun eta beas".

Para pembantu Abah dalam urusan kerumahtanggaan berjumlah sembilan

\footnotetext{
${ }^{5}$ kolot $=$ orang tua; kokolot $=$ tetua.

${ }^{6}$ Rendangan adalah sekelompok orang yang memiliki keyakinan yang sama dengan pimpinan adat, dengan kata lain rendangan merupakan pengikut sebuah komunitas adat kasepuhan (lihat Rosyadi dkk., 2005: 40).
} 
orang, yakni (Rahmawati dkk., 2008: 176) tukang moro, tukang paraji, tukang bersih, tukang suguh, tukang benteng, tukang kemit, tukang goah, tukang sisiuk, dan tukang canoli.

Dari seluruh struktur kepemimpinan adat di Kasepuhan Sinarresmi, hampir seluruhnya diemban berdasarkan keturunan, hanya kolot lembur yang ditunjuk secara langsung oleh Abah. Tentunya dengan kriteria tersendiri sesuai dengan yang diinginkan oleh Abah.

"Aturan karuhun kudu dikeukeuhan, dikukukuhan, dipageuhan. Aturanana tilu sapamulu, dua sakarupa, nи hiji eta-eta keneh, kudu diterapkeun kana perilaku urang sapopoe. Kedah ngajaga tekad, ucap, perilaku, sara nagara mokaha kedah kakaulaan"

Artinya aturan leluhur harus dipegang dengan kuat. Sebagaimana halnya aturan tilu sapamulu, dua sakarupa, nu hiji etaeta keneh harus diterapkan dalam kehidupan sehari-hari. Setiap niatan, ucapan dan perilaku masyarakat di Kasepuhan Sinarresmi harus selalu terjaga, sedangkan sara, nagara, mokaha harus selalu terlayani dengan baik.

Konsep ini kemudian diejawantahkan dalam sistem kepemimpinan adat tradisional di mana staf ahli bidang agama (sara) dan negara dapat melengkapi tugas dan fungsi kasepuhan yang harus menselaraskan antara sara, nagara dan mokaha. Sehingga mereka dapat menjalankan fungsinya dalam melengkapi tugas Abah sebagai pimpinan adat tertinggi (Rahmawati dkk., 2008: 173-174).

Konsep sara, nagara dan mokaha yang terdapat dalam sistem kepemimpinan tradisional di Kasepuhan Sinarresmi memiliki fungsinya masing-masing, yaitu :

1. Sara, mengurus hal-hal yang berkaitan dengan ibadah agama. Oleh karena itu mayoritas di Kasepuhan Sinarresmi beragama Islam, maka pemimpin sara ini disebut kiai.

2. Mokaha, artinya salamet dipimpin langsung oleh $A b a h$ selaku pimpinan adat di Kasepuhan Sinarresmi. Abah bertugas memimpin ritual dan upacara-upacara yang ada di Kasepuhan Sinarresmi.

3. Nagara, adalah wakil abah dalam menangani masalah kenegaraan, fungsinya untuk menjembatani kepentingan adat, masyarakat dan pemerintahan desa maupun dunia luar.

Sebagai pemimpin Abah diharuskan melanjutkan pesan dan wasiat dari karuhun kepada para incu putu-nya. Selain menjaga dengan kuat tradisi leluhur khususnya dalam melaksanakan sistem pertanian tradisional, Abah juga senantiasa mengingatkan masyarakat melalui petuahpetuah bijak yang senantiasa diyakini kebenarannya oleh para incu putu-nya. "cing hade dak jaga, cirina urang teh mun geus euweuh leuit bakal timbul beurit, mun teu ngukus bakal timbul tikus".

Artinya berhati-hatilah nak, salah satu ciri apabila leuit sudah tidak ada maka akan muncul beurit, apabila tidak memberikan sesajian maka akan muncul juga tikus. Makna dari ungkapan tersebut bahwa seluruh masyarakat di Kasepuhan Sinarresmi harus mampu menjaga keberadaan leuit sebagai warisan leluhur agar tidak tergeser oleh budaya luar, begitu pula berbagai macam ritual yang menyertai keberadaan leuit harus dipertahankan.

\section{Leuit}

Sekitar 95\% warga Kasepuhan Sinarresmi berprofesi sebagai petani, baik itu petani pemilik maupun petani penggarap. Sistem pertanian ini digarap secara tradisional yang didasarkan pada aturan adat, sehingga penggunaan alat atau bahan-bahan kimia dalam pertanian dilarang. Benih padi yang ditanam warga Kasepuhan Sinarresmi juga harus benih padi varietas lokal dan musim tanam hanya dilakukan satu kali dalam satu tahun. Hal ini dilakukan selain untuk menjaga keberlangsungan varietas lokal juga sebagai ketahanan pangan warga kasepuhan. Terbukti jenis padi varietas lokal mampu bertahan lama apabila disimpan di dalam leuit, dibandingkan dengan jenis padi varietas unggulan. 
Alasan pelarangan penggunaan padi bibit, karena hal tersebut bertentangan dengan aturan adat yang tidak memperkenankan melakukan komersialisasi produk pertanian padi. Hal ini juga didukung oleh perolehan hasil panen padi lokal yang tidak sebanyak padi jenis unggulan, sehingga mereka tidak memperjualbelikannya demi keuntungan ekonomi, tetapi disimpan dalam leuit untuk kebutuhan pangan sehari-hari.

Leuit atau dalam istilah umum disebut lumbung padi, yaitu sebuah bangunan tradisional khas warga kasepuhan. Leuit berfungsi untuk menyimpan gabah kering hasil panen padi yang memiliki kemampuan tahan cuaca, tahan hama penyakit, dan memiliki sistem tata udara yang baik sehingga gabah kering dapat disimpan dalam jangka waktu yang lama. Padi yang disimpan di dalam leuit dapat awet hingga puluhan tahun. Semakin lama padi disimpan di dalam leuit, semakin nikmat rasanya dan bijinya semakin berwarna merah serta teksturnya mengeras.

Selain memiliki fungsi yang bersifat sosial, ternyata leuit juga dibentuk berdasarkan konsep budaya yang bersifat kosmologis, sehingga memiliki nilai-nilai filosofis yang bersifat sakral, yang dipercaya dan dipertahankan oleh warga masyarakat di Kasepuhan Sinarresmi hingga kini. Keberadaan leuit menjadi bagian yang tidak terpisahkan dari kehidupan mereka sebagai petani. Mereka percaya bahwa selama masyarakat adat kasepuhan masih ada, selama itu pula padi dan leuit akan terus ada.

Masyarakat Kasepuhan Sinarresmi percaya bahwa padi merupakan titisan Nyai Sri Pohaci (Dewi Sri) yang berjasa memberikan mereka penghidupan melalui pertanian, sehingga mereka memperlakukan pertanian dan padi dengan penuh hormat dan sakral. Padi diibaratkan manusia yang harus dijaga. Apabila manusia tinggal di dalam rumah maka padi juga harus diberi rumah, yaitu leuit tadi. Apabila manusia hidup berpasangan, maka padi pun ada yang bersifat laki-laki dan perempuan. Apabila manusia lahir dari seorang ibu maka padi pun memiliki ibu yang disebut indung pare.

Sebagai bentuk penghormatan kepada Sang Hyang Sri, selain menganalogikan padi kepada manusia, pola pertanian yang dilakukan juga sangat sarat dengan ritual. Terdapat berbagai macam ritual adat dari awal menanam padi hingga panen raya tiba. Sebagai puncaknya adalah upacara seren taun.

Upacara seren taun merupakan puncak dari seluruh rangkaian upacara tradisional yang harus dilakukan oleh masyarakat Sinarresmi terkait dengan padi. Setelah upacara seren taun selesai maka masing-masing kepala rumah tangga beserta istrinya harus melaksanakan prosesi ritual ngadiukkeun pare di leuit.

Sebelum ritual dimulai, pemilik leuit harus menyiapkan sesaji dan sawen. Sawen berfungsi sebagai benda penolak bala atau papadon. Sawen terdiri atas: dadap, jukut palias, rameyuke, darangdan, jawer kotok, tulak tanggul, sulangkar, dan pacing. Sawen digulung menjadi satu kemudian diikat dan diselipkan di keempat dinding leuit, serta satu buah lagi diselipkan di atas pintu leuit.

Baru kemudian dilaksanakan ritual ngadiukkeun pare indung sebanyak 4-5 pocong kecil. Satu pocongan padi dibuat menjadi 5 gedeng/pocongan kecil sebesar ibu jari. Ke-4 pocongan indung pare yang akan didiukeun, disusun secara melingkar, dan terakhir ditutup dengan pocongan ke-5 di atasnya. Indung pere yang akan didiukkeun, dilakukan secara bersamasama oleh suami dan istri di tengah leuit. Pada saat ritual ngadiukkeun, panglai disemburkan di setiap sudut leuit, baru kemudian menyelipkan sawen di luar leuit, dan terakhir menggariskan kapur cikur yang berfungsi untuk menandai bahwa di leuit tersebut telah selesai dilaksanakan ritual ngadiukkeun pare indung.

Leuit dibangun dengan menggunakan bahan-bahan alami yang dapat diperoleh sendiri tanpa harus membeli. 
Sekalipun begitu, umur leuit mampu bertahan hingga puluhan tahun tergantung dari perawatan yang dilakukan. Rangka leuit dibangun dari kayu hulubatu, dindingnya terbuat dari anyaman bambu, sedangkan atapnya terbuat dari gabungan hateup dan ijuk, sedangkan dasarnya dialasi daun teureup $^{7}$ sebanyak 2 lapis. Ukuran leuit bervariasi, yang kecil biasanya berukuran $2,5 \times 3 \mathrm{~m} 2$, sedangkan yang paling besar dapat mencapai ukuran 3 $\mathrm{x} 5 \mathrm{~m} 2$.

Pembangunan leuit dibuat oleh yang ahli di bidangnya atau juga gotong royong. Sebelum membangun leuit pemilik menentukan hari baik terlebih dahulu, lalu meminta izin kepada Abah dengan membawa seperangkat sesajian untuk didoakan supaya pembangunannya berjalan lancar tanpa kendala. Sebuah leuit dengan ukuran kecil dapat selesai dibangun selama 2-3 hari. Leuit biasanya ditempatkan di sekitar perkampungan tidak terlalu jauh dari rumah pemiliknya.

\section{a. Leuit Pribadi}

Leuit pribadi merupakan leuit yang dimiliki secara individu oleh setiap warga masyarakat Kasepuhan Sinarresmi yang telah berumah tangga. Sekalipun tidak memiliki sawah, setidaknya mereka harus memiliki satu buah leuit di samping rumahnya. Leuit dapat dijadikan tolok ukur kesejahteraan masyarakat, semakin banyak sebuah rumah tangga memiliki leuit, semakin tinggi pula tingkat kesejahteraan dan status ekonominya.

\section{b. Leuit Komunal}

Pada setiap rendangan terdapat leuit komunal atau masyarakat setempat biasa menyebutnya leuit kasatuan $^{8}$. Leuit

\footnotetext{
${ }^{7}$ Daun teureup yaitu daun berjenis lebar yang berfungsi untuk menjaga kelembaban padi di dalam leuit dari udara luar.

${ }^{8}$ Leuit kasatauan atau leuit paceklik adalah lumbung -lumbung padi milik kokolot lembur yang berada di kampung-kampung kasepuhan yang bertujuan untuk mengatasi masalah
}

kasatuan ini dibangun di tanah milik Abah yang ada di tiap rendangan. Leuit ini dibangun secara gotong royong oleh warga lembur. Bentuk dan ukurannya seperti leuit biasa yang dimiliki oleh warga masyarakat pada umumnya yaitu $2,5 \times 3 \mathrm{~m} 2$.

Pengelolaan leuit di setiap rendangan menjadi tanggung jawab para olot lembur. Mekanisme setoran padi pada leuit kasatuan di masing-masing rendangan, hampir sama dengan setoran pada leuit si jimat yang terdapat di imah gede. Jumlah setoran ke leuit rendangan adalah sebanyak satu ikat padi per keluarga. Leuit kasatuan juga diisi oleh padi hasil maro kolot lembur di lahan adat milik Abah.

Biasanya setiap panen raya tiba, tukang tamba kakayaan ${ }^{9}$ mendata jumlah hasil panen padi yang dihasilkan setiap kampung. Pendataan ini dibutuhkan untuk memperoleh hasil riil kekayaan setiap warga kasepuhan, selain itu pendataan juga berfungsi untuk menghitung jumlah setoran padi yang harus disetor ke leuit si jimat atau ke leuit Abah. Setelah diketahui berapa jumlah panen pada setiap kampung, hasilnya kemudian dilaporkan kepada Abah. Setelah itu Abah menghitung berapa banyak padi yang harus disetor ke leuit si jimat pada setiap kampung. Jumlah panen yang dilaporkan adalah hasil bersih setelah dikurangi atau dipotong jekat, bibit dan resiko. Sehingga padi yang disetorkan ke leuit si jimat merupakan akumulasi bersih dari keseluruhan hasil panen padi di Kasepuhan Sinarresmi.

Selain terdapat konsep setoran atau pajak bumi dari masyarakat kepada $A b a h$ yang sifatnya wajib, juga ada semacam sumbangan yang bersifat sukarela dari masyarakat, yang biasanya diberikan pada

ketahanan pangan (khususnya ketersediaan padi) (Rosyadi,dkk., 2005: 87).

9 Tukang tamba kakayaan merupakan bagian dari struktur pemerintahan adat Kasepuhan Sinarresmi, mereka bertugas membantu Abah dalam mendata hasil panen padi pada setiap lembur/rendangan yang mengikut ke Kasepuhan Sinarresmi. 
saat ada acara besar di imah gede. Masing-masing kepala rendangan membawa lagi beras untuk dimasak bersama-sama pada saat acara diselenggarakan, bahkan warga juga memeriahkannya dengan membawa serta berbagai macam penganan seperti lauk pauk, lalaban dan hahampangan.

Adapun leuit komunal yang biasanya terdapat disetiap kampung, berfungsi sebagai cadangan atau bekel incu putu, artinya setiap masyarakat diperbolehkan untuk meminjam padi yang terdapat di dalam leuit adat kasepuhan bilamana dalam perjalanannya sebelum panen raya tiba yang bersangkutan sudah kehabisan padi di leuit-nya. Masyarakat bebas untuk meminjam padi sesuai dengan kebutuhannya dengan catatan harus mengembalikannya setelah panen musim tanam berikutnya.

Mereka akan mendatangi kolot lembur agar bisa meminjam beras dari leuit kasatuan. Pada saat meminjam, kolot lembur tidak harus memperhatikan berapa jumlah padi yang mereka ambil di leuit, saling percaya satu sama lain menjadi kunci utamanya.

\section{c. Leuit Si Jimat}

Leuit si jimat merupakan salah satu jenis bangunan tradisional yang memiliki nilai sakral yang berada di sekitar imah gede Kasepuhan Sinarresmi. Leuit si jimat yang memiliki dimensi bangunan sebesar $3 \times 5$ meter 2 dengan tinggi tiang yang diukur dari permukaan tanah hingga lantai bangunan setinggi $30 \mathrm{~cm}$. Pada leuit si jimat terdapat ornamen hiasan yang terbuat dari kembang bubuay atau disebut juga hoe leuweung.

Sekalipun letak leuit si jimat ini berada persis di samping imah gede, yang merupakan tempat kediaman abah, namun demikian leuit si jimat ini tidak berarti dimiliki secara pribadi oleh Abah, tetapi sebaliknya merupakan leuit komunal yang menjadi hak milik semua warga kasepuhan Sinarresmi.
Hal ini juga sesuai dengan kata jimat pada leuit si jimat yang berasal dari kata "nyimat", yang artinya meminjam. Kata nyimat juga bisa diartikan sebagai makna kasih sayang (kadeudeuh, kanyaah). Jadi leuit si jimat merupakan sebuah leuit yang diperuntukkan untuk meminjam bagi warga masyarakat kasepuhan sebagai wujud kasih sayang Abah terhadap incu putunya.

Leuit si jimat memiliki fungsi sebagai lumbung ketahanan pangan bagi semua warga kasepuhan. Apabila dalam perjalanannya menuju panen raya tahun berikutnya, ada warga incu merasa kekurangan bekel (padi) di leuit-nya maka warga yang bersangkutan dapat meminjamnya di leuit si jimat, untuk selanjutnya dibayar setelah panen raya tiba, sesuai dengan jumlah padi yang dipinjamnya pada saat itu.

Pada saat musim panen tiba, setiap warga kasepuhan yang telah berkeluarga atau setiap rumah tangga diwajibkan untuk melakukan tatali (menyimpan padi) di si jimat sesuai dengan kemampuannya. Besaran jumlah tatali biasanya disesuaikan dengan hasil panen yang diperoleh. Apabila satu rumah tangga memperoleh padi sebanyak 50 ikat pocong maka dia wajib ngalung ke leuit si jimat sebanyak satu pocong, apabila 100 pocong ngalung dua pocong, begitu seterusnya. Berat ratarata satu pocong padi kurang lebih sekitar $7 \mathrm{~kg}$. Oleh sebab itu leuit si jimat disebut juga leuit pangalungan.

Berbeda dengan tatali, terdapat juga sebuah sistem ketahanan pangan dan sosial di Kasepuhan Sinarresmi yang disebut dengan jekat ${ }^{10}$. Menurut Abah Asep bahwa incu putu yang telah memperoleh padi dari hasil panen raya, harus mengeluarkan jekat sesuai dengan besaran hasil panen mereka. Adapun perbandingan 10:1, artinya setiap

\footnotetext{
${ }^{10}$ Konsep jekat ini pada dasarnya mengadopsi konsep zakat yang umumnya dikenal oleh umat Islam sebagai ibadah yang memiliki nilai sosial di mana setiap penghasilan atau harta yang diperoleh harus dikeluarkan zakatnya untuk kepentingan umat.
} 
10 ikat padi yang dihasilkan harus dikeluarkan 1 ikat. Pemberian jekat ini diprioritaskan untuk orang tua, saudara, dan fakir miskin. Aturan mengeluarkan jekat ini boleh dikatakan wajib, sebab menurut Abah Asep apabila seseorang belum mengeluarkan jekat padinya maka dia tidak dapat menyimpan padi ke dalam leuit.

Sebuah leuit mampu menampung hingga 2000 -an pocong padi. Satu pocong padi beratnya sekitar 3-4 kg. Adapun sagedeg $^{11}$ beratnya bisa mencapai $7 \mathrm{~kg}$ (Rosyadi dkk., 2005: 84). Leuit si jimat memiliki kapasitas yang lebih besar daripada leuit-leuit lainnya, karena ukuran leuit si jimat yang cukup besar maka daya tampung leuit si jimat hingga antara 30004000 ikat padi.

Proses memasukkan padi ke leuit si jimat dilakukan satu tahun sekali yaitu ketika diselenggarakan upacara seren taun. Padi-padi yang telah terkumpul hasil tatali dari seluruh warga incu putu abah, kemudian dikumpulkan dan diarak dengan iringan ritual dan tarian sebagai penanda bahwa panen raya telah tiba, saatnya masyarakat menikmati hasil jerih payahnya dengan terlebih dahulu memasak padi yang baru dipanen, yang disebut dengan nganyaran. Pada saat seren taun dilaksanakan, secara simbolis Abah memasukkan beberapa pocong padi ke dalam leuit si jimat sebagai simbol kemakmuran seluruh masyarakat adat Kasepuhan Sinarresmi.

Ritual seren taun yang dijadikan sebagai simbol rasa syukur atas keberhasilan panen raya dengan hasil padi yang melimpah setiap tahunnya, juga merupakan sebuah simbol kemakmuran yang memang patut dibanggakan oleh seluruh warga kasepuhan kepada masyarakat luar. Terbukti selama bertahun-tahun tradisi ritual seren taun dilaksanakan di bawah kepeminpinan Abah Asep belum pernah sekalipun padi yang

${ }^{11}$ Sagedeg padi berarti 2 pocong padi yang diikat menjadi satu. Dan satu rengkong atau pikulan padi bisa terdiri dari 4 gedegan. berada di leuit si jimat dikeluarkan untuk menanggulangi bencana paceklik, karena stok padi yang ada di masing-masing leuit warga kasepuhan masih sangat mencukupi kebutuhan mereka.

Akan tetapi menurut Abah Asep dahulu pada masa kepemimpinan Abah Ujat, pernah terjadi paceklik selama 3 tahun, sehingga banyak warga incu putu Abah yang harus meminjam padi ke leuit si jimat. Bagi mereka yang akan meminjam padi dari leuit si jimat terlebih dahulu harus meminta izin Abah atau pamit ka Abah "Bah bade nyimat bekel" (Bah mau meminjam padi). Abah tidak harus melihat dan membawakan padi untuk mereka ke leuit, mereka sendiri yang membawanya sesuai dengan kebutuhannya. Begitu pula ketika mereka akan mengembalikannya, mereka juga harus memberitahu Abah "Bah pare tos diuihkeun" (Bah padi sudah dikembalikan). Abah harus percaya bahwa jumlah pocongan padi yang dipinjam dan dikembalikan oleh warga pasti sesuai.

Bagi masyarakat adat di Kasepuhan Sinarresmi, berbicara mengenai padi merupakan hal yang sangat sakral, sehingga untuk menghormatinya, nilainilai kejujuran, kepatuhan, dan kepatutan pada setiap hukum adat tetap dipertahankan. Hukum adat mengatakan maruh, nyawa, jiwa, artinya setiap aturan adat merupakan nyawa atau bagian dari kehidupan mereka, jadi tidak akan ada yang menyalahgunakan ketentuan hukum adat yang berlaku.

\section{Fungsi Kepemimpinan Adat dalam Mendorong Solidaritas Sosial}

Leuit yang berfungsi sebagai lumbung ketahanan pangan bagi masyarakat di Kasepuhan Sinarresmi, memegang peranan penting dalam menjaga keberadaan mereka di dunia ini. Sebagaimana ungkapan yang telah disampaikan di atas, bahwa "mun geus teu aya leuit bakal timbul beurit", yang dimaknai sebagai peringatan bahwa masyarakat harus senantiasa menjaga keberadaan leuit di daerah mereka, sebab bila leuit sudah 
tidak ada akan terjadi hal-hal yang tidak diinginkan yang dapat merusak kehidupan mereka, sebagaimana halnya tikus yang bersifat menggerogoti.

Begitu pula halnya dengan leuit si jimat dan leuit kasatuan yang ada di Kasepuhan Sinarresmi, harus juga dijaga keberadaannya. Keberadaan leuit si jimat dan leuit kasatuan sangat bergantung kepada masyarakat, karena tanpa adanya partisipasi aktif dari masyarakat ngalung ka leuit si jimat, leuit ini tidak akan pernah terisi, selanjutnya leuit si jimat juga akan kehilangan fungsi sosialnya sebagai lumbung padi komunal.

Tradisi tatali berupa ngalung $k a$ leuit si jimat merupakan wujud solidaritas sosial yang bersifat mekanistis, yang terjadi ketika anggota masyarakat merasa saling percaya dan memiliki rasa kesetiakawanan yang tinggi yang menyebar merata pada seluruh lapisan sosial. Selain itu juga adanya unsur kepatuhan kapada Abah sebagai pemimpin adat, yang didasarkan pada adanya unsur kepercayaan dan pemujaan. Kedua unsur ini sangat kuat mengakar pada diri setiap masyarakat di Kasepuhan Sinarresmi yang masih teguh memegang adat dan pikukuh karuhun. Sementara pada posisi sebaliknya konsep nyimat (meminjam) pare ka leuit si jimat merupakan perwujudan kongkrit dari adanya solidaritas sosial.

Selain itu ada juga tradisi lain yaitu jekat, yang juga memiliki fungsi sosial yang sama dengan tradisi tatali sebagai perwujudan solidaritas sosial masyarakat di Kasepuhan Sinarresmi. Meski demikian, tradisi jekat ini tidak menjadikan leuit sebagai perantara, melainkan secara langsung antaranggota masyarakat.

Dengan kata lain leuit menjadi semacam pengikat solidaritas sosial di antara sesama warga kasepuhan, hal ini disebabkan adanya sebuah kesadaran kolektif untuk menaati nilai-nilai religius yang melekat pada leuit, yang pada dasarnya menjadi bagian dari sistem adat di Kasepuhan Sinarresmi.
Sebagaimana yang diungkapkan Durkheim bahwa, adanya solidaritas sosial pada sebuah kelompok memungkinkan mereka memenuhi kehidupannya sendiri, tanpa harus bergantung kepada kelompok lain. Artinya dengan adanya konsep nyimat, masyarakat yang membutuhkan beras tidak harus pusing memikirkan kemana harus mencari, tetapi solusinya telah ada di dalam komunitasnya, yaitu dengan tersedianya leuit si jimat yang dapat dimanfaatkan sebagai penyedia talangan beras ketika membutuhkan.

Solidaritas sosial ini dapat terjadi pada masyarakat di Kasepuhan Sinarresmi, karena mereka termasuk ke dalam kelompok masyarakat sederhana, yang masih memiliki keterikatan dan kepentingan yang sama di dalam kelompoknya. Keterikatan sebagai incu putu Abah yang dituntut untuk saling membantu antara satu dengan yang lainnya dalam kesulitan dan kesusahan hidup. Mereka juga memiliki kepentingan yang sama, yaitu menjaga dan melestarikan amanat karuhun dalam setiap nafas kehidupan mereka. Persamaan yang terbentuk dengan sendirinya ini, pada akhirnya menjadi sebuah kekuatan sosial yang selalu mengedepankan sikap kebersamaan dan solidaritas. Sebagaimana yang dilakukan pada tradisi tatali melalui konsep ngalung dan nyimat $k a$ leuit si jimat.

Solidaritas sosial yang terbentuk pada masyarakat di Kasepuhan Sinarresmi pada dasarnya juga dipengaruhi oleh adanya unsur percaya dan patuh kepada Abah. Sebagai seorang pemimpin adat yang berkharisma, tentunya Abah memiliki strategi-strategi tertentu untuk melanggengkan kepercayaan dan kepatuhan masyarakat kepadanya. Berdasarkan itulah diperlukan adanya suatu stimulus dari pemimpin yang dapat terus mempertahankan kebiasaan masyarakat melakukan tradisi tatali (ngalung) ka leuit si jimat. Di sinilah faktor pemimpin adat (Abah) sangat berperan khususnya dalam menjaga tradisitradisi terkait pertanian dan leuit supaya 
terus dilaksanakan oleh masyarakat pendukungnya.

Kewenangan tradisional yang dimiliki Abah dalam menjalankan fungsinya sebagai pemimpin adat, memungkinkan beliau menerapkan sanksi adat terhadap pelanggaran-pelanggaran aturan adat. Selain itu Abah sering pula mengiangkan petuah-petuah dan ajaranajaran karuhun yang disampaikan baik kepada masyarakat secara langsung ataupun melalui para baris kolot, maupun kepada orang luar yang ingin mempelajari kearifan lokal mereka. Kedua hal tersebut sebetulnya menjadi kunci penting bagi Abah dalam menjaga tradisi dan melanggengkan kekuasaannya.

Kepatuhan terhadap aturan karuhun serta pituah Abah dan para kokolot lainnya, menjadi benteng masyarakat dalam menangkal hal-hal negatif dari luar yang dapat melunturkan ketaatan mereka dalam menjalankan kehidupan yang bersahaja. Sesuai dengan moto hidup mereka cukup sandang, cukup pangan. Hanya perlu untuk hidup berkecukupan sesuai dengan porsinya saja, tanpa harus berlebihan apalagi menghamburkan untuk hal-hal yang tidak perlu.

\section{PENUTUP}

Berdasarkan uraian panjang lebar mengenai leuit dengan fungsinya sebagai lumbung padi komunal, dan konsep solidaritas sosial yang tersemat kepadanya maka penelitian ini kemudian menemukan bahwa solidaritas sosial yang muncul dalam pemanfaatan leuit, selain karena terbentuk dengan sendirinya sebagai perwujudan sikap kebersamaan dan keterikatan sebagai anggota masyarakat adat Kasepuan Sinarresmi, juga diperkuat oleh adanya sikap patuh terhadap aturan-aturan adat yang dijaga oleh pemimpin adat.

Hal ini dapat berarti pula bahwa masyarakat adat Kasepuhan Sinarresmi mematuhi aturan dan perintah Abah. Sistem pelapisan sosial yang bersifat tertutup serta unsur kepemimpinan tradisional yang bersifat pemujaan, di antara masyarakat dan pemimpin adat, menguatkan sikap patuh masyarakat terhadap Abah. Sebaliknya sikap patuh masyarakat terhadap aturan adat yang dijaga oleh Abah, dimanfaatkan untuk melanggengkan sistem kepercayaan dan nilai-nilai yang telah dipercayai oleh pemimpin dan masyarakat adat.

\section{DAFTAR SUMBER}

\section{Jurnal, Makalah, Laporan Penelitian, Skripsi, dan Tesis}

Purnama, Yuzar, Iwan Roswandi, Nina, Merlina, Hikmat Nasrullah, Wildan Nirmala, Ayi Syarif. 2012.

Fungsi Leuit pada Masyarakat Kasepuhan Cicarucub Banten. Laporan Penelitian. Bandung: Balai Pelestarian Nilai Budaya Bandung.

Merlina, Nina. 2003.

Fungsi Leuit bagi Masyarakat Desa Cidikit, Kecamatan Bayah, Kabupaten Lebak. Laporan Penelitian. Bandung : Balai Kajian Sejarah dan Nilai Tradisional Bandung.

Rahmawati, Rita, Subair, Idris, Gentini, Dian Ekowati, Usep Setiawan. "Pengetahuan Lokal Masyarakat Adat Kasepuhan: Adaptasi, Konflik, Dinamika SosioEkologis" dalam Sodality: Jurnal Transdisiplin Sosiologi, Komunikasi, dan Ekologi Manusia Vol. 2 No. 2. Agustus 2008. Hlm. 151-190.

Rosyadi, Suwardi Alamsyah, Agus Heryana, Ria Andayani Somantri, Lina Herlinawati, Aam Masduki. 2005.

Peranan Leuit dalam Kehidupan Masyarakat Kasepuhan Cisungsang di Desa Cisungsang, Kecamatan Cibeber, Kabupaten Lebak Banten. Laporan Penelitian. Bandung: Balai Kajian Sejarah dan Nilai Tradisional Bandung.

Saifullah. 2015.

Solidaritas Sosial Buruh Nelayan dalam Meningkatkan Perekonomian Masyarakat Desa Beluk-Kenek Kecamatan Ambuten Kabupaten Sumenep. Skripsi. Surabaya: UIN Sunan Ampel Surabaya. 


\section{Buku}

Adimihardja, Kusnaka. 1992.

Kasepuhan yang Tumbuh di Atas yang Luruh. Bandung: Tarsito.

Herdiansyah, Haris. 2010.

Metodologi Penelitian Kualitatif untuk Ilmu-Ilmu Sosial. Jakarta: Salemba Humanika.

Iskandar, Johan. 2001.

Manusia, Budaya, dan Lingkungan (Ekologi Manusia). Bandung: Humaniora Utama Press.

Iskandar, Johan dan Budiawati S. Iskandar, 2011.

Agroekosistem Orang Sunda. Bandung: Kiblat Buku Utama.

Iver, Mc. 1980.

Jaring-jaring Pemerintahan. Jakarta: Aksara Baru.

James M, Henselin. 2006.

Sosiologi dengan Pendekatan Membumi. Jakarta: Gelora Aksara Pratama.

James, Pip. 2009.

Pengantar Teori-Teori Sosial. Jakarta: Yayasan Obor Indonesia.

Mustapa, Hasan. 2010.

Adat Istiadat Sunda. Edisi ke-3 Cetakan ke-1. Bandung: Alumni.

Saryono. 2010.

$\begin{array}{llr}\text { Metodologi } & \text { Penelitian } & \text { Kualitatif } \\ \text { dalam } & \text { Bidang } & \text { Kesehatan. } \\ \text { Yogyakarta: Nuha Medika. }\end{array}$

Scott John (editor). 2011.

Sosiologi The Key Concepts. Jakarta: Rajawali Press.

Setiadi, Elly M. dan Usman, Kolip. 2011.

Pengantar Sosiologi. Pemahaman Fakta dan gejala Permasalaha Sosial: Teori, Aplikasi, dan Pemecahannya. Jakarta: Kencana.

Soekanto, Soerjono. 2013.

Sosoilogi Suatu Pengantar. Cetakan ke45 edisi revisi. Jakarta: Rajawali Press.

Soemarwoto, Otto. 1994.

Ekologi, Lingkungan Hidup dan Pembangunan. Cetakan ke-6 edisi revisi. Jakarta: Djambatan.

\section{Internet}

Diakses dari http://www.omtani.com/ 2015 103/program-intensifikasi-pertanianrevolusi-hijau.html, tanggal 2 Februari 2016, pukul 10.45 wib. 